\title{
Details of motorcycle accidents and their impact on healthcare costs
}

\author{
Serkan Emre Eroğlu, M.D.,, ${ }^{1}$ Sıddıka Nihal Toprak, M.D.,, Ebru Akoğlu, M.D.,, ${ }^{2}$ \\ Özge Ecmel Onur, M.D., ${ }^{1}$ Arzu Denizbaşı, M.D., ${ }^{1}$ Çiğdem Özpolat, M.D., ${ }^{1}$ Haldun Akoğlu, M.D. ${ }^{1}$
}

\author{
'Department of Emergency Medicine, Marmara University Pendik Training and Research Hospital, Istanbul \\ ${ }^{2}$ Department of Emergency Service, Mersin Toros State Hospital, Mersin \\ ${ }^{3}$ Department of Emergency Service, Ataturk State Hospital, Emergency Service, Zonguldak
}

\begin{abstract}
BACKGROUND: Of overall traffic accidents in $201 \mathrm{I}$ in Turkey, $7.58 \%(\mathrm{n}=21,107)$ were motorcycle accidents. Motorcycle accidents and their impact on healthcare costs are investigated in our study.

METHODS: Motorcycle accidents that occurred with/without a collision between I July 2010 and 30 June 201 I were studied prospectively through the inspection of patients visiting the Emergency Service. The healthcare costs relevant to each person injured in a motorcycle accident were investigated via forms. Data were analyzed using frequencies, Kolmogorov-Smirnov, Mann-Whitney $U$, and chi-square tests on the SPSS v16.0 program.

RESULTS: Ninety-one people involved in accidents, with a mean age of 28.47 years, were studied. The average healthcare expenditure for the 91 patients studied between reception and discharge was US\$253.02 (median, US\$55.90; range, US\$I I.52 - 7I37.19). According to our study, there was no definitive correlation between the healthcare costs and the time of the accident, motorcycle type, nature of the road surface, protective equipment, weather, or daylight.
\end{abstract}

CONCLUSION: According to the current study, the risk of an accident increases with young adults. Concordantly, healthcare costs increase. Thus, it is important that the legal rules with respect to the age and education necessary for receiving a license to operate a motorcycle should be redefined, and if necessary, regulated.

Key words: Emergency department, healthcare costs, motorcycle accidents, trauma.

\section{INTRODUCTION}

It is estimated that 1.2 million people are killed and 50 million injured worldwide due to traffic accidents each year. ${ }^{[1]}$ Based on the Turkish National Police Traffic Services Department, in 20I I, 2,582 fatalities were reported in Turkey resulting from 278,353 traffic accidents. Of Turkey's overall traffic accidents, $7.58 \%(n=21,107)$ were motorcycle-related. ${ }^{[2]}$ Today, motorcycles are regarded as a good solution to bypass heavy traffic,

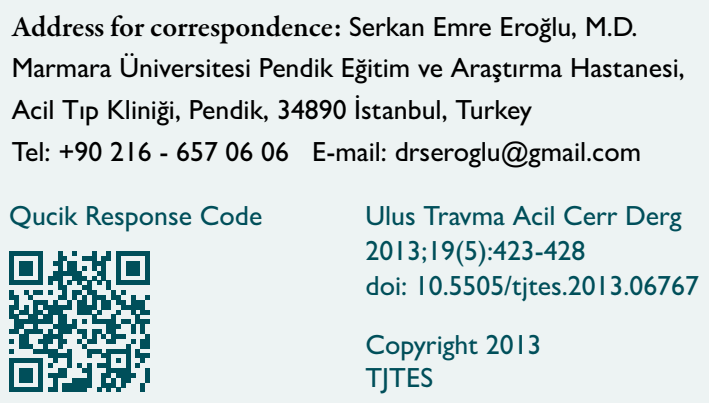

and as an economical and convenient vehicle, and this suggests that the number of motorcycle accidents is likely to increase in the future. We may also assume that motorcycle accidents will cause higher fatalities and result in higher healthcare costs. Motorcycle accidents and the impact of these accidents on healthcare costs are investigated in this study.

\section{MATERIALS AND METHODS}

\section{Setting}

We surveyed motorcycle and pillion riders involved in accidents with or without collision between I July 2010 and 30 June 20II who were treated in the Emergency Service of Mersin Toros State Hospital. During this prospective study, we planned that the injured people as well as the witnesses would be required to fill in the forms in the presence of the physician on duty.

\section{Study form}

The form contained data fields concerning the demographic features of the injured person, the type of motorcycle, details 
of the accident, weather and road conditions during the accident, and the protective equipment worn, as well as the healthcare features and the total expenditures generated.

The total expenditure for the total period of hospitalization was entered in the forms later by the surveyors. The expenditures were recorded in Turkish lira and converted to US dollar using the exchange rate of I.7I TL/US\$, which was the average rate of exchange between I July 2010 and I July $201 \mathrm{I}$.

\section{Data analysis}

The data collected were analyzed with the Statistical Package for the Social Sciences (SPSS) v16.00 software. The average values are presented with a $95 \%$ confidence interval (Cl) in this study. The concordance of the relative variables to the normal distribution was evaluated via the KolmogorovSmirnov (K-S) test. For the statistics of non-parametrical data, the chi-square and Mann-Whitney $U$ tests were employed.

\section{Ethical issues}

The Institutional Review Board approved the study. Verbal consent was obtained after explaining the consent statement. The study was conducted in accordance with the principles of the Declaration of Helsinki. Informed consent was acquired from all interviewees.

\section{RESULTS}

\section{Characteristics of the patients and the collision}

The mean age of the 91 people involved in an accident was 28.47 years (95\% Cl, 25.94-3I.0I), while the median age was 25 years (range, 5-67). Thirteen people (27.65\%) involved in accidents with a collision who presented to the Emergency Service were below 18 years old, 15 (31.91\%) were between 18 and 25,9 (19.14\%) were between 26 and 34, and 10 (21.27\%) were between 35 and 50 years. Only 2 (4.25\%) of the injured were over 50 . Of all the people studied, 81 (89\%) were male; $74.7 \%(n=68)$ of patients were riders and $25.3 \%$ $(n=23)$ were pillion riders. Of the injured, $50.5 \%(n=46)$ were wearing helmets and $3.3 \%$ of the injured had other protective equipment. Only $3 \%$ of the patients were helmet-wearing pillion riders. Among the 10 injured females, only I was wearing a helmet. All the females not wearing helmets were pillion riders. The average speed of the motorcycles $(n=91)$ was $31.15 \mathrm{~km} / \mathrm{h}(95 \% \mathrm{Cl} 27.6 \mathrm{I}$ - 34.69; range, 0 - $100 \mathrm{~km} / \mathrm{h})$, and the other vehicles in motion during the accident had an average speed of $38.08 \mathrm{~km} / \mathrm{h}(95 \% \mathrm{Cl} 30.6 \mathrm{I}-45.56 \mathrm{~km} / \mathrm{h}$; range, $5-100 \mathrm{~km} / \mathrm{h}$ ). Forty-seven of the accidents (5l.6\%) involved a collision (no pedestrians involved), $4 \mathrm{l}$ of the accidents (45. $1 \%$ ) did not involve a collision (fall, skid, etc.), and 3 of the accidents involved a collision with a pedestrian. Nine of the accidents with a collision (19.2\%) involved smashing a parked car, and 4 of them involved a fixed object (wall, barrier, etc.).

Seasonal, environmental and situational factors

The greatest number of injuries $(n=24,26.4 \%)$ occurred in the month of March, while the least number of injuries $(n=I$, I.I\%) occurred in August. The distribution of motorcycle accidents that involved injuries are broken down by season as follows: 16 injuries in summer (June, July, August) (17.6\%), II in autumn (September, October, November) (12.1\%), I5 in winter (December, January, February) (16.5\%), and 49 in spring (March, April, May) (53.8\%). Of the accidents, $79.1 \%$ $(n=72)$ occurred during daylight. Fourteen of $19(73.7 \%)$ nighttime accidents occurred under artificial light conditions, and 12 of the day-time accidents (16.7\%) occurred during cloudy weather (Table I). 15.4\% of all accidents $(n=14)$ occurred during rainy weather, and $2.2 \%(n=2)$ occurred during misty weather. No snow was encountered in any of the accidents studied. No statistically significant difference was encountered between patient discharge and the daylight status, lighting of the accident area (sunny, cloudy, dark, artificial light), or rain condition $(p=0.097, p=0.372, p=0.192$, respectively).

Roads/boulevards and local streets were the most common locations reported for the accidents (Table I). $80.2 \%$ of accidents $(n=73)$ occurred on dry-asphalt, whereas $11.0 \%(n=10)$ occurred on slippery surfaces (Table I). Sixty-three patients involved in accidents on asphalt (dry) surfaces and 9 patients involved in accidents on slippery surfaces were discharged. No statistically significant difference was found between the methods of discharge from the Emergency Service and the condition of the surface.

\section{Method of discharge from the Emergency Service} Seventy-nine of the patients $(86.8 \%)$ were discharged, I (I.I\%) was transferred to another health institution, 10 (I I.0\%) were hospitalized, and I died in the Emergency Service during treatment. Four of the hospitalized patients were observed in the intensive care unit. The only patient who died was female, and she was a pillion rider not wearing a helmet.

Of the 68 motorcycle riders involved in accidents, 61 (89.7\%) were discharged, 4 (5.9\%) were hospitalized, and $3(4.4 \%)$ were monitored in the intensive care unit. Of 23 pillion riders, 18 (78.3\%) were discharged, 2 (8.7\%) were hospitalized, and I (4.3\%) was monitored in the intensive care unit.

\section{Situations that affect the pattern of discharge from emergency service}

\section{Gender}

In our study, $60.0 \%(n=6)$ of female patients and $90.1 \%$ of male patients were discharged. The discharge pattern (discharge, overnight stay, transfer, exitus) of patients showed a statistically significant relationship with gender $(p=0.00$ I, $\chi^{2}$ test). According to the additional analysis undertaken on the relationship between gender and the method of discharge from the Emergency Service, the relationship was statistically significant at a level of $p<0.001$ (Mann-Whitney $U$ test), while other patterns of discharge from the Emergency Service showed no relationship (hospitalization, transfer). Thus, 
Table I. Medium and mechanism of accidents and motorcycle data

\begin{tabular}{|c|c|c|c|c|c|}
\hline \multicolumn{3}{|c|}{ Accident medium and motorcycle data } & \multicolumn{3}{|l|}{ Mechanism of accident } \\
\hline & $\mathbf{n}$ & $\%$ & & $\mathbf{n}$ & $\%$ \\
\hline Place of accident & & & Type of accident & & \\
\hline Highway & 5 & 5.5 & With collision (vehicle, fixed object) & 47 & 51.6 \\
\hline Main street/boulevard & 36 & 39.6 & Without collision (fall, skid) & 41 & 45.1 \\
\hline Side street & 29 & 31.9 & Collision with pedestrian & 3 & 3.3 \\
\hline Road junction & 7 & 7.7 & & & \\
\hline Traffic light & 4 & 4.4 & & & \\
\hline Other & 10 & 11.0 & & & \\
\hline Surface & & & First point of impact - motorcycle & & \\
\hline Asphalt (dry) & 73 & 80.2 & Front & 40 & 44.0 \\
\hline Slippery & 10 & 11.0 & Rear & 13 & 14.3 \\
\hline Soil & 4 & 4.4 & Sides & 38 & 41.8 \\
\hline Other & 4 & 4.4 & & & \\
\hline Lighting condition & & & First point of impact - person & & \\
\hline Daytime-sunny & 60 & 65.9 & Head/neck & 10 & 11.0 \\
\hline Daytime-cloudy & 12 & 13.2 & Shoulder & 6 & 6.6 \\
\hline Night-time-dark & 5 & 5.5 & Arm/forearm & 13 & 14.3 \\
\hline \multirow[t]{3}{*}{ Night-time-lightened medium } & 14 & 15.4 & Hand/wrist & 19 & 20.9 \\
\hline & & & Chest & 3 & 3.3 \\
\hline & & & Abdomen & 3 & 3.3 \\
\hline Motorcycle type & & & Waist/back & 5 & 5.5 \\
\hline Sports & 19 & 20.9 & Hip/pelvis & 4 & 4.4 \\
\hline Off-road/endurance & 3 & 3.3 & Led/mid-calf & 15 & 16.5 \\
\hline Scooter/moped & 61 & 67.0 & Foot/ankle & 19 & 12.1 \\
\hline Chopper-cruiser & 1 & I.I & Left blank & 2 & 2.2 \\
\hline Other & 7 & 7.7 & & & \\
\hline
\end{tabular}

discharge of patients from the Emergency Service was higher among females than males.

\section{Mechanism of the accident}

Of the patients involved in an accident with a collision, 38 (48.1\%) were discharged, and of those that were involved in an accident without a collision, 38 (48.1\%) were discharged. The number of people admitted to the intensive care unit was also the same. Two people involved in an accident without a collision were admitted to the intensive care unit. The only patient who died presented to the Emergency Service after an accident that involved a collision. No statistically significant difference was detected between the pattern of discharge and the nature of the accident (with collision, without collision, collision with a pedestrian). Further, no statistically significant difference was detected between the pattern of discharge and the use of helmets or other protective gear (with collision, without collision, collision with a pedestrian).

\section{Type of motorcycles}

Among the types of motorcycles involved in accidents, scooter or mopeds $(n=61,67.0 \%)$ were the most common (Table I). Of those, 54 of the injured $(88.5 \%)$ were discharged from the Emergency Service, 3 (4.9\%) were hospitalized in various services, and 2 (3.3\%) were admitted to the intensive care unit. The oldest of 19 patients who had accidents riding a sports motorcycle (the second most common) was 44 years old, the median age was 22 years, and the mean age was 26.37 years (95\% Cl 20.78 - 31.96). Sixteen of these patients were discharged from the Emergency Service (84.2\%), and 2 were admitted to the intensive care unit (10.5\%). Upon evaluation, no statistically significant difference was found between the pattern of discharge from Emergency Service and the type of motorcycle ridden.

The first area of impact of the motorcycle and the body Using the information supplied by the people involved in the accidents or from witnesses, it was found that for $54.9 \%$ 
$(n=50)$ of the incidents, the component having the first impact was the person. The most common first area of impact of the body was the hand and wrist, and the most common first area of impact of the motorcycle was the front (Table I). Whether the first point of contact was the person or the motorcycle made no difference on the fact that the most common first area of impact of the body was the hand and wrist. In our study, there was a statistically significant difference between the first point of impact on the person and the pattern of discharge from the Emergency Service $(p=0.009)$. On the other hand, no statistically significant difference was found between the first point of impact on the motorcycle and the pattern of discharge from the Emergency Service. Since the K-S test did not show normal distribution, Mann-Whitney $U$ test was performed, and it detected no statistically significant difference in the healthcare expenditures with regard to whether the motorcycle or the person suffered the fist impact.

\section{Main symptoms on admission}

Of the patients hospitalized after a motorcycle accident, 87 of 91 (95.6\%) were conscious and I was unconscious (I.1\%) during admission. Two patients (2.2\%) were drowsy, and I was in cardiac arrest. Seventy-nine $(90.8 \%)$ of the 87 patients who were conscious at the time of admission were discharged from the Emergency Service. The correlation between the state of consciousness at the time of admission and the type of discharge was statistically significant $(p<0.001)$.

According to the statements of patients or accompanying people, the most common injury involved the extremities $(n=56,61.5 \%)$ of the body. This was followed by the head and neck $(n=20,22.0 \%)$ and torso $(n=13,14.3 \%)$. Two patients presented without injury. Eleven patients suffered cuts, and all II were discharged. No statistically significant difference was observed between method of discharge and the patients with cuts. Four of six patients $(66.7 \%)$ requiring service follow-ups were brought into the Emergency Service with complaints about the extremities, whereas three of four patients $(75.0 \%)$ requiring intensive care were brought with complaints regarding the torso. One patient who was admitted to the intensive care unit was observed with consciousness problems. Of 79 patients discharged, 5 I (64.6\%) were brought to the Emergency Service with injuries of the extremities. The second most common injury observed in the patients who were discharged concerned the head and neck $(n=18,22.8 \%)$. The correlation between the method of discharge and the localization of injuries was statistically significant $(p=0.005)$.

\section{Other situations}

No statistically significant difference was found upon analysis between the methods of discharge and whether the injured was a rider or on a pillion. On the contrary, the correlation between the road type and the method of discharge was statistically significant $(p=0.014)$. All of the injured people involved in accidents occurring at traffic lights and road junc- tions were discharged $(n=4, n=7$, respectively). Six patients were hospitalized, and of these, three were involved in accidents that occurred on main streets/boulevards, and the other three were involved in accidents that occurred on side streets. Again, three of four patients who were admitted to the intensive care unit were involved in accidents that occurred on local streets. Seventy-nine patients were discharged, of whom, 33 (4I.8\%) were involved in accidents that occurred on main streets/boulevards, and 23 (29.1\%) were involved in accidents that occurred on side streets.

\section{Healthcare costs}

During this study, the healthcare costs for the scanning and treatment of the injured were also noted. According to our study, the most common scanning technique was $X$-ray monitoring $(n=78,85.7 \%)$, followed by blood testing $(n=65$, $71.4 \%)$, computed tomography $(n=26,28.6 \%)$, ultrasonography $(n=5,5.5 \%)$ and magnetic resonance monitoring $(n=2$, $2.2 \%$ ). The healthcare expenditure of 91 people studied between reception and check-out was US\$253.02 on average (95\% Cl 55.0I - 45I.03), the midpoint being US\$55.90. The lowest healthcare expenditure was US\$II.52 and the highest was US\$7,137.19. The total healthcare expenditure for all presenting patients was US\$23,025. Using a K-S test, it was observed that there was not a normal distribution for the healthcare costs of either the female or male patients. MannWhitney $U$ test was carried out for this purpose, and it was observed that there was no statistically significant difference between genders in terms of healthcare cost.

In this study, the injured parts of the body and the healthcare expenditures were studied independently, and there was no difference in the average healthcare expenditures between injuries of the upper and lower extremities. However, the average healthcare costs for head and neck injuries were higher than for the upper or lower extremities, and this showed a statistically significant difference $(p=0.03$ and $p=0.02$, Mann$W$ hitney $U$ test). Further, the healthcare costs were studied in relation to the site of the accident. No statistically significant difference was found in the average healthcare costs according to site of the accident, as on a main street/boulevard or side street, or at a road junction. However, a statistically significant difference was observed between accidents that took place on these roads and those occurring on highways $(p=0.02$, Mann-Whitney $U$ test). Healthcare expenditure was observed to be higher with respect to the highway accidents.

\section{DISCUSSION}

Our study was conducted in the Emergency Service of Toros State Hospital in Turkey. Mersin's hospitals cover the healthcare needs of the $1,648,000$ inhabitants of this province $\left(15,737 \mathrm{~m}^{2}\right) .^{[3]}$ According to the Turkish National Institute, the city in which this study was conducted reportedly had 444,734 registered motorized land vehicles, of which, I 3 I,394 $(29.5 \%)$ were motorcycles. ${ }^{[4]}$ Based on information from the 
Turkish National Police Traffic Services Department, the number of total traffic accidents in $201 \mathrm{I}$ was 6,510 , resulting in 78 deaths. ${ }^{[2]}$ The healthcare expenditures related to these accidents are not well known. In our study, we investigated the factors influencing these expenditures.

\section{The risk of an accident increases with young adults}

As shown in our study, the majority of the people involved in accidents were between 20 and 30 years of age, which is a result consistent with many other studies. ${ }^{[5-8]}$ Also consistent with these same studies, we found that motorcycle accidents more frequently involved young adults, and the risk of being involved in an accident with a collision decreased with increased age. It may be suggested that age is a factor that affects the choice of vehicles, but this should not be taken as the only and absolute reason, since another study carried out in Turkey on judicial cases reported that young people tend to take actions with greater risk due to their inexperience, and as a result, they have the highest risk of being injured in motorized vehicle accidents. ${ }^{[9]}$ In parallel with our study, most of the people injured in an accident with a sports bike (whether as a rider or on the pillion) are young, supporting this opinion.

In contrast to the literature, the injuries are related to the upper extremity

In contrast to many studies in the related literature, most of the applications were related to upper extremity injuries. ${ }^{[10-13]}$ Our records show that injuries to the upper limb were in the majority. The first point of impact of the body was also highest for the upper extremity. This fact has remained constant regardless of the nature of the accident, and this may be associated with age. The average age in our study was young. Because of more rapid reflex responses in younger people, they are able to use their hands more easily to protect their head and body during an accident. This may have contributed to this result. In addition, since the accidents mostly occurred in the city areas, this may cause motorcycles to move slower and thus result in less severe accidents. Finally, this can be seen as another reason for having fewer organ injuries than extremity injuries. We also found in our study that highway accidents are associated with a higher expenditure although they are fewer in number. It is also important to note that the severity of highway accidents covered in our study was not severe. Another result also helps us to conclude that the severity of accidents covered in our study is low: We did not observe any statistically significant relationship between the time of accident, motorcycle type, road surface, weather and daylight conditions, or the nature of the discharge of the patient from the Emergency Service (discharged, hospitalized, or exitus).

The use of the helmet alone is not effectively related to healthcare costs

Many studies from the past ${ }^{[14-16]}$ showed many results indicating the importance of wearing helmets. Brown et al. ${ }^{[16]}$ found that riding and crashing a motorcycle without a helmet is associated with more frequent and more severe injuries, longer hospitalizations, increased mortality, and significantly higher hospital charges, which are often not covered by healthcare insurance. Nevertheless, although the helmet use in women is low, their rate of discharge was higher compared to that of men, a fact that demonstrates that helmet use alone is not effective in relation to the healthcare costs. However, since 8 of II of the hospitalized patients were not wearing helmets, it remains an important factor.

The effect of the type of the accident is compatible with previous studies

The most common type of accident encountered in our study was front collision, which agrees with that reported by Zulkipli et al. ${ }^{[17]}$ We also found that the number of accidents occurring at traffic lights and junctions is lower. This can lead us to consider that front collisions may be a result of careless riding or failure to maintain a safe following distance. Thus, in an effort to reduce motorcycle accidents, it is necessary to improve the traffic awareness of motorcyclists as well implement into practice a penalty mechanism.

In conclusion, many factors can influence the healthcare costs related to the way in which motorcycle accident victims pass through an emergency room. We did not observe any statistically significant relationship between the time of the accident, motorcycle type, road surface, weather and daylight conditions, or the protective equipment used, although these variables looked promising. The main factor that determines the healthcare costs is the first part of the body receiving the impact. Another important result is that motorcycle accidents have become a form of trauma specific to the young. It is important that the legal authorities redefine the rules, and if necessary, regulate the age and education necessary to receive a license to operate motorcycles.

The facts that this study was held in one city and in a single healthcare center (far from the highway) are the most serious limiting factors, preventing this study from including many severe multi-trauma patients. Future studies planned involving multiple healthcare centers, with more detailed questions on the accidents, will better outline the factors that influence healthcare costs.

\section{Acknowledgements}

We would like to thank Dr. Ray Guillery for the English edition of the manuscript and also thank the Institutional Review Board for their kind approval of this study.

Conflict of interest: None declared.

\section{REFERENCES}

1. Peden M, Scurfield R, Sleet D, Mohan D, Hyder A, Jarawan E, et al. World report on road traffic injury prevention. Geneva: World Health Organization; 2004.

2. Turkish National Police, Traffic Services Department [Homepage on the 
internet]. Ankara: Traffic statistics yearbook 2011, Turkey.

3. Eroglu SE, Toprak SN, Urgan O, Onur OE, Denizbasi A, Akoglu H, et al. Evaluation of non-urgent visits to a busy urban emergency department. Saudi Med J 2012;33:967-72.

4. Turkish statistical institute [Homepage on the internet]. Ankara: Road motor vehicles by province, Turkey [cited 2012 June 20]. Available from: http://www.turkstat.gov.tr/PreHaberBultenleri.do?id=10861.

5. Monk JP, Buckley R, Dyer D. Motorcycle-related trauma in Alberta: a sad and expensive story. Can J Surg 2009;52:235-40.

6. Elliott MA, Baughan CJ, Sexton BF. Errors and violations in relation to motorcyclists' crash risk. Accid Anal Prev 2007;39:491-9.

7. Zambon F, Hasselberg M. Socioeconomic differences and motorcycle injuries: age at risk and injury severity among young drivers. A Swedish nationwide cohort study. Accid Anal Prev 2006;38:1183-9.

8. Nakahara S, Chadbunchachai W, Ichikawa M, Tipsuntornsak N, Wakai $\mathrm{S}$. Temporal distribution of motorcyclist injuries and risk of fatalities in relation to age, helmet use, and riding while intoxicated in Khon Kaen, Thailand. Accid Anal Prev 2005;37:833-42.

9. Ayoğlu F, Isık AF, Bumin MA. Gazi Üniversitesi Tip Fakültesi Acil Servisine başvuran adlî vakaların analizi. V. Ulusal Halk Sağlığı Kon- gresi. İstanbul: 1996. s. 96-100.

10. Chiu WT, Kuo CY, Hung CC, Chen M. The effect of the Taiwan motorcycle helmet use law on head injuries. Am J Public Health 2000;90:793-6.

11. Özkan S, İkizceli İ, Akdur O, Durukan P, Güzel M, Vardar A. Injuries due to motorcycle accidents. JAEM 2009;8:25-9.

12. Lateef F. Riding motorcycles: is it a lower limb hazard? Singapore Med J 2002;43(11):566-9.

13. Koçak S, Uçar K, Bayır A, Ertekin B. Characteristics of the cases of bicycle and motorcycle accidents referred to the Emergency Department. TJ Emerg Med 2010;10:112-8.

14. Hinds JD, Allen G, Morris CG. Trauma and motorcyclists: born to be wild, bound to be injured? Injury 2007;38:1131-8.

15. Liu BC, Li L, Gao M, Wang YL, Yu JR. Microinflammation is involved in the dysfunction of arteriovenous fistula in patients with maintenance hemodialysis. Chin Med J (Engl) 2008;121:2157-61.

16. Brown CV, Hejl K, Bui E, Tips G, Coopwood B. Risk factors for riding and crashing a motorcycle unhelmeted. J Emerg Med 2011;41:441-6.

17. Zulkipli ZH, Abdul Rahmat AM, Mohd Faudzi SA, Paiman NF, Wong SV, Hassan A. Motorcycle-related spinal injury: crash characteristics. Accid Anal Prev 2012;49:237-44.

\section{KLINIK ÇALIŞMA - ÖZET}

\section{Motorsiklet kazaları detayları ve sağlık maliyetleri üzerine etkileri}

\section{Dr. Serkan Emre Eroğlu, ${ }^{1}$ Dr. Sıddıka Nihal Toprak, ${ }^{2}$ Dr. Ebru Akoğlu, ${ }^{3}$ Dr. Özge Ecmel Onur, ${ }^{1}$ Dr. Arzu Denizbaşı, ${ }^{1}$ Dr. Çiğdem Özpolat, ${ }^{1}$ Dr. Haldun Akoğlu ${ }^{1}$}

${ }^{1}$ Marmara Üniversitesi Pendik Eğitim ve Araştırma Hastanesi, Acil Tıp Kliniği, İstanbul ${ }^{2}$ Mersin Toros Devlet Hastanesi, Acil Servis, Mersin

${ }^{3}$ Atatürk Devlet Hastanesi, Acil Servis, Zonguldak

AMAÇ: Türkiyede 201 I yılındaki tüm trafik kazalarının \%7.58'ini ( $n=2$ I I07) motorsiklet kazaları oluşturmaktadır. Çalısmamızda, motorsiklet kazaları ve bu kazalara ait detayların, sağık maliyetlerindeki rolleri araştııılı.

GEREÇ VE YÖNTEM: I Temmuz 20।0-30 Haziran 20।I tarihleri arasında çarpışmalı ya da çarpışmasız motorsiklet kazaları ile acil servise gelen hastalar ileriye dönük olarak incelendi. Kazazede ve kazaya ait detaylı bilgileri içeren formlar motorsiklet kazası ile getirilen tüm yaralılara doldurularak sağılk maliyetleri araştırıldı. Veriler, SPSS v 16 programında frekans, Kolmogorov-Smirnov, Mann-Whitney U ve ki-kare testleri kullanılarak analiz edildi. BULGULAR: Değerlendirmeye alınan 9| kazazedenin, yaş ortalaması 28.47. Değerlendirmeye alınan 9| kazazedenin başvurusundan taburculuğuna kadar olan sağlık maliyetleri ortalaması 253.02\$, ortancası $55.90 \$$ idi (dağılım, II.52- 7|37.19\$). Çalışmaya göre, sağlık maliyetleri ile kaza saati, motorsiklet tipi, yolun yüzeyi, koruyucu ekipman, hava ya da gün ışı̆̆ı arasında kesin bir korelasyon yoktu.

TARTIŞMA: Çalışmaya göre, kaza riski genç erişkinlerle artmaktadır. Buna bağlı olarak da, sağlık maliyetleri artmaktadır. Bu sebeple, yasal kuralları yeniden belirlenmesi ve gerekiyorsa motorsiklet ehliyeti alma yaşı ve de eğitimleri düzenlenmelidir.

Anahtar sözcükler: Acil servis, sağlık maliyetleri, motorsiklet kazaları, travma.

Ulus Travma Acil Cerr Derg 2013; 19(5):423-428 doi: 10.5505/tjtes.2013.06767 